\title{
PERAN KOMUNIKASI ORANG TUA DALAM MENINGKATKAN MINAT BELAJAR ANAK DI MASA PANDEMI COVID 19
}

\author{
Durotunnisa dan Nur Eka Wahyuningsih Riyadi
}

\begin{abstract}
Islam views that the first education carried out is family education. The educational situation is realized thanks to the association and the relationship of mutual influence between parents and children. Allah swt gives a lot of descriptions of how parents should educate their children in the Qur'an, which in general education must be based on love for children. During the COVID-19 pandemic, the role of parents in children's education is even greater at home. Because learning that is carried out online, either through zoom meetings, classroom, google meet, whatsapp and other applications, limits the monitoring or supervision of teachers on children's learning activities, this task is now the responsibility of parents. Many cases occur in online learning, especially the problem of children's interest in learning which generally shows poor results. This can be seen from the lack of attention of children in the tasks given by the teacher, slow in collecting until they do not do the task, children are lazy in following the learning process and so on. Regarding this problem, the author sees that the role of parents is very important in increasing children's interest in learning, namely by implementing effective communication both verbally and non-verbally, by always providing advice, motivation, encouragement and education about the importance of learning even though it is only done online. Through this, it is hoped that there will be an increase in children's interest in learning so that children's learning achieves better and maximum results.
\end{abstract}

Keywords: Parental Communication, Children's learning interests, Covid 19 Pandemic

\section{PENDAHULUAN}

Komunikasi merupakan hal yang mendasar bagi kehidupan manusia, sebagai makhluk sosial yakni makhluk yang mempunyai kebutuhan untuk berinteraksi atau berhubungan dengan orang lain, komunikasi sangatlah diperlukan. Melalui komunikasi manusia dapat saling berhubungan satu sama lain dalam kehidupan 
sehari-hari baik dirumah, di sekolah maupun dimasyarakat. Dengan komunikasi pula manusia dapat mengerti dirinya sendiri, mengerti orang lain dan memahami lingkungannya, mengetahui tempat dan cara kehadirannya di masyarakat serta hubungan dengan orang-orang yang berada disekitarnya

Komunikasi adalah suatu proses dimana seseorang atau beberapa orang, kelompok, organisasi dan masyarakat menciptakan dan menggunakan informasi agar terhubung dengan lingkungan dan orang lain. Menurut Marheini Fajar komunikasi bertujuan sebagai perubahan perilaku, perubahan pendapat, perubahan sikap dan perubahan sosial. ${ }^{1}$ Artinya setelah komunikasi dilakukan diharapkan akan terjadi sebuah perubahan baik perubahan perilaku, perubahan pendapat, perubahan sikap dan perubahan sosial. Misalnya dari perilaku atau sikap seseorang yang semula tidak baik menjadi baik serta pendapat seseorang yang semula kurang tepat menjadi lebih tepat.

Menurut Hafied Cangara ada tiga fungsi dasar yang menjadi penyebab mengapa manusia perlu berkomunikasi, yaitu pertama, adanya hasrat manusia untuk mengontrol lingkungannya. Melalui komunikasi dapat mengetahui suatu kejadian bahkan dapat mengembangkan pengetahuannya yaitu dengan cara belajar dari pengalaman maupun dari informasi yang dapat diterima dari lingkungan sekitarnya. Kedua, adanya upaya manusia untuk beradaptasi dengan lingkungannya. Artinya dengan berkomunikasi telah menjadi sebuah tanda adanya upaya dari seseorang untuk berbaur dan beradaptasi dengan lingkungan sekitarnya. Ketiga, adanya upaya untuk melakukan transformasi warisan sosialisasi. Suatu masyarakat yang ingin mempertahankan keberadaannya, maka anggota masyarakatnya dituntut untuk melakukan pertukaran nilai, perilaku, dan peranan. Misalnya bagaimana orang tua mengajarkan tatakrama kepada anaknya, dimana sekolah difungsikan untuk mendidik calon penerus bangsa dan bagaimana pemerintah dengan kebijaksanaanya yang dibuat untuk mengayomi kepentingan masyarakat yang dilayaninya. ${ }^{2}$

\footnotetext{
${ }^{1}$ Marheini Fajar, Ilmu Komunikasi, Teori dan Praktek, Edisi 1 (Yogyakarta: Graha Ilmu, 2009), 60

${ }^{2}$ Hafied Cangara, Pengantar Ilmu Komunikasi, (Jakarta: PT. Raja Grafindo Persada, 2006), 3.
} 
Berdasarkan hal tersebut, terlihat bahwa betapa pentingnya komunikasi bagi kehidupan manusia. Untuk dapat berkomunikasi dengan baik dan efektif, seseorang dituntut untuk tidak hanya memahami prosesnya, tetapi juga mampu menerapkan pengetahuannya secara kreatif.

Tidak dapat dipungkiri jika terjadi komunikasi yang kurang baik maka akan berdampak pada tujuan keduanya (komunikator dan komunikan) yaitu makna pesan yang mungkin tidak akan tercapai. Utamanya dalam menghadapi persoalan pendidikan yang saat ini banyak terjadi di masa pandemi covid 19, yang menuntut banyak pihak untuk melakukan sebuah perubahan bagi kelangsungan proses pendidikan untuk anak. Salah satunya yakni adanya tuntutan peran orang tua untuk meningkatkan minat belajar anak.

Minat merupakan perhatian yang mengandung unsur-unsur perasaan. Minat juga menentukan suatu sikap yang meyebabkan seseorang berbuat aktif dalam suatu pekerjaan. Degan kata lain minat dapat menjadi sebab dari suatu kegiatan. ${ }^{3}$ Minat juga diartikan sebagai suatu kondisi yang terjadi apabila seseorang melihat ciri- ciri atau arti sementara situasi yang dihubungkan dengan keinginan-keinginan atau kebutuhan-kebutuhannya sendiri. ${ }^{4}$

Berdasarkan pendapat tersebut pada dasarnya minat adalah penerimaan akan suatu hubungan antara diri sendiri dengan sesuatu hal diluar dirinya. Semakin kuat atau dekat hubungan tersebut semakin besar minatnya. Proses belajar mengajar akan berjalan dengan lancar jika disertai dengan minat. Minat diartikan sebagai suatu kondisi yang terjadi apabila seseorang melihat ciri-ciri atau arti sementara yang dihubungkan dengan keinginan-keinginan atau kebutuhan-kebutuhan sendiri.

Minat yang besar terhadap sesuatu merupakan modal yang besar untuk mencapai benda atau tujuan yang diamati. Minat belajar yang besar juga cenderung menghasilkan prestasi yang tinggi, sebaliknya minat belajar yang kurang akan menghasilkan prestasi yang rendah. Adanya kasus penurunan minat belajar anak

\footnotetext{
${ }^{3}$ Mahfud S., Pengantar Psikologi Pedidikan, (Cet. 4, Surabaya: PT. Bina Ilmu, 2001), 92.

${ }^{4}$ Sardiman, Interaksi dan Aktivitas Belajar Mengajar, (Jakarta: Rajawali Pers, 2004), 76.
} 
akibat proses pembelajaran daring yang dilakukan di Rumah memerlukan perhatian khusus dari orang tua yang harus aktif dalam melakukan komunikasi guna mencapai keberhasilan belajar belajar anak secara maksimal.

\section{PEMBAHASAN}

\section{Kajian Tentang Komunikasi Orang tua terhadap Anak}

\section{Pengertian Komunikasi}

Secara etimologis, komunikasi berasal dari bahasa latin, yaitu cum, sebuah kata depan yang artinya dengan atau bersama dengan, dan kata units sebuah kata bilangan yang berarti satu. Dua kata tersebut membentuk kata benda communio, yang dalam bahasa Inggris disebut dengan communion yang berarti kebersamaan, persatuan, persekutuan gabungan, pergaulan, atau hubungan. Karena untuk bercommunio diperlukan adanya usaha dan kerja, kata itu dibuat untuk kata kerja communicate yang berarti membagi sesuatu dengan seseorang, tukar menukar, membicarakan sesuatu dengan orang, memberitahukan sesuatu kepada seseorang, bercakap-cakap, bertukar pikiran, berhubungan, dan berteman. ${ }^{5}$ Jadi, jika dua orang terlibat komunikasi, maka komunikasi itu dapat dikatakan berhasil apabila ada kesamaan makna mengenai apa yang dikomunikasikan. Kesamaan bahasa yang digunakan belum tentu menimbulkan kesam aan makna. ${ }^{6}$

Pengertian secara umum komunikasi adalah proses penyampaian suatu pernyataan yang dilakukan oleh seseorang kepada orang lain sebagai konsekuensi dari hubungan sosial. ${ }^{7}$ Ilmu komunikasi adalah ilmu yang mempelajari usaha penyampaian pesan antar manusia, objek ilmu komunikasi adalah komunikasi, yakni usaha penyampaian antar manusia. ${ }^{8}$

${ }^{5}$ U. Saefullah, Manejemen Pendidikan Islam (cet. 1, Bandung: Pustaka Setia, 2012), 177.

${ }^{6}$ Nikmah Hadiati Salisah, Ilmu Komunikasi (Pasuruan: LunarMedia, 2012), 25.

5.

${ }^{7}$ Onong Uchjana Effendy, Dinamika Komunikasi, (Bandung: PT. Remaja Rosda Karya, 2000), 56.

${ }^{8}$ Nurani Soyomukti, Pengantar Ilmu Komunikasi, (Jogjakarta: Ar- Ruzz Media, 2010), 
Effendi mengatakan bahwa komunikasi merupakan suatu kesamaan dalam arti sama makna, apabila ada dua orang terlibat dalam komunikasi, misalnya dalam bentuk percakapan, maka komunikasi akan terjadi atau berlangsung selama ada kesamaan makna mengenai apa yang dipercakapkan. ${ }^{9}$

Komunikasi hanya bisa dilakukan oleh dua pihak atau dua orang, atau dengan kata lain komunikasi lahir karena adanya interaksi yang dilakukan oleh minimal dua orang. Kedua pihak kemudian berbagi informasi guna memenuhi kebutuhan masingmasing, dengan terpenuhinya kebutuhan maka manusia bisa mempertahankan kelangsungan hidupnya. Sehingga hidupnya menjadi berkembang dari waktu ke waktu. Dapat dikatakan bahwa komunikasi merupakan interaksi atau hubungan yang dilakukan seseorang kepada orang lain dalam rangka memenuhi kebutuhan hidupnya. ${ }^{10}$ Gode juga berpendapat bahwa komunikasi adalah suatu proses yang membuat sesuatu yang semula dimiliki oleh seseorang (monopoli seseorang) menjadi dimiliki dua orang atau lebih. ${ }^{11}$

Berdasarkan pendapat tersebut di atas, dapat disimpulkan bahwa komunikasi merupakan sebuah bentuk interaksi yang dilakukan oleh dua orang atau lebih dalam rangka menyampaikan pesan dengan cara yang berbeda-beda, sehingga akan mendapatkan sebuah respon. Olehnya itu, komunikasi antara orang tua terhadap anak yang dimaksud yaitu suatu interaksi yang dilakukan oleh orang tua dengan anak dalam lingkungan keluarga untuk memberikan kehangatan, kenyamanan, perhatian, kasih sayang bimbingan, yang memberikan contoh perilaku yang baik kepada anak dan menanamkan nilai budi pekerti yang baik, yang bertujuan agar terbentuk perilaku yang baik kepada anak dalam lingkungan keluarga, sekolah maupun masyarakat.

${ }^{9}$ Onong Uchjana Effendi, Ilmu Komunikasi Teori dan Praktek (Cet. 20, Bandung: Rosdakarya, 2007), 9.

${ }^{10}$ Abdullah Munir, Membangun Komunikasi Efektif: Sebuah Upaya Mewujudkan Sekolah yang Membahagiakan (Yogyakarta: Mentari Pustaka, 2012), 4.

${ }^{11}$ Vardiansyah, Filsafat Ilmu Komunikasi, (Jakarta: PT Indeks Gramedia, 2005), 25. 


\section{Dasar dan tujuan Komunikasi}

Pada dasarnya komunikasi bertujuan untuk memberikan informasi, mendidik dan menerangkan informasi bahkan menghibur komunikan. agar komunikan terpengaruh dan berubah sifat sesuai dengan kehendak komunikator dan untuk mempengaruhi tingkah laku si penerima informasi yang dinyatakan dalam tindakantindakan tertentu sebagai respons terhadap informasi yang diterimanya.

Manusia adalah makhluk sosial yang membutuhkan interaksi dengan manusia lain dan alam disekitarnya (interaksi sosial) untuk mendukung kelangsungan hidupnya. Dalam berinteraksi itulah dibutuhkan komunikasi baik dalam bahasa verbal (bahasa lisan/tulisan) maupun bahasa isyarat (bahasa tubuh/simbol). Dalam Islam komunikasi dibutuhkan untuk saling mengenal, menyampaikan pesan, saling bekerja sama, berbuat kebajikan dan lain sebagainya, baik untuk tujuan-tujuan kemasyarakatan, keagamaan maupun tujuan individual ${ }^{12}$

Firmah Allah swt dalam surah Al-hujurat ayat 13:

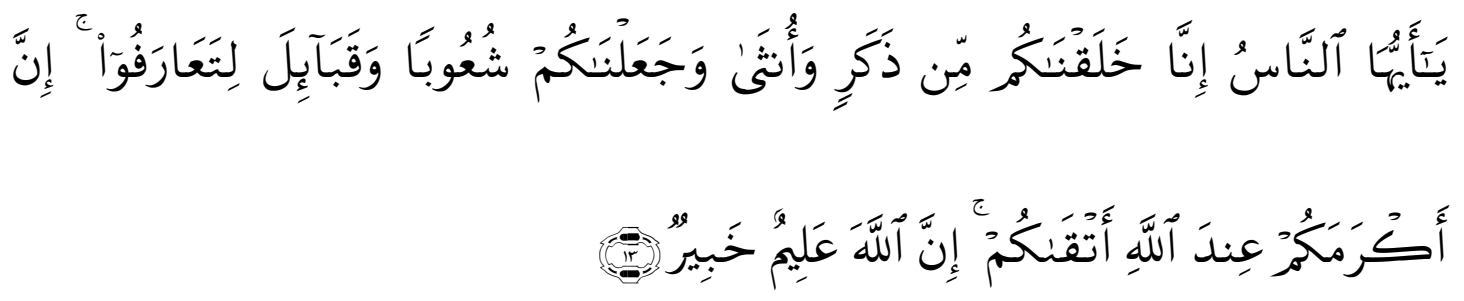

Terjemahnya:

"Hai manusia, Sesungguhnya Kami menciptakan kamu dari seorang laki-laki dan seorang perempuan dan menjadikan kamu berbangsa-bangsa dan bersuku-suku supaya kamu saling kenal-mengenal. Sesungguhnya orang yang paling mulia diantara kamu disisi Allah ialah orang yang paling taqwa diantara kamu. Sesungguhnya Allah Maha mengetahui lagi Maha Mengenal."13

\footnotetext{
${ }^{12}$ Akhmad Muhamimin Azzet, Urgensi Pendidikan Karakter di Indonesia, (Jogjakarta: Ar-Ruzz Media, 2011), 47

${ }^{13}$ Depar temen Agama RI, Al-Qur'an dan Tafsirnya, (Jakarta: Lentera Abadi,2010), 419.
} 
Dengan demikian tujuan komunikasi sebenarnya adalah untuk mencapai pengertian bersama, sesudah itu mencapai persetujuan mengenai suatu pokok ataupun masalah yang merupakan kepentingan bersama. Dengan kondisi yang demikian akan terjalin hubungan yang harmonis dan saling mengerti satu sama lain dalam rangka mencapai tujuan yang telah ditetapkan bersama. Dalam Islam komunikasi juga bisa dijadikan media untuk ibadah yaitu dengan cara berlaku baik atau berbuat kebajikan kepada sesama manusia, alam maupun Tuhan. Komunikasi juga merupakan sarana untuk terus menjalin silaturrahmi dengan sesama manusia baik dalam keseharian di dunia nyata maupun melalui media komunikasi.

\section{Bentuk-bentuk Komunikasi}

Bentuk-bentuk komunikasi antara lain:

\section{a. Komunikasi Verbal}

Menurut Paulette J. Thomas dalam Onong Uchjana Effendy mengemukakan bahwa komunikasi verbal adalah penyampaian dan penerimaan pesan dengan menggunakan bahasa lisan dan tulisan. ${ }^{14}$ Adapun kode komunikasi verbal dalam pemakaiannya menggunakan bahasa, bahasa dapat didefinisikan seperangkat kata yang telah disusun secara berstruktur sehingga inti kalimat yang mengandung arti. ${ }^{15}$

Berdasarkan definisi di atas, dapat disimpulkan bahwa komunikasi verbal adalah komunikasi yang menggunakan symbol-simbol atau kata-kata, baik yang dikatakan secara oral, lisan maupun tertulis.

Kegiatan komunikasi verbal harus dilakukan dilingkungan keluarga. Sebab orang tua yang baik akan setiap hari berbincang-bincang dengan anaknya. Baik dalam bentuk Perintah, suruhan, larangan, candaan dan lain sebagainya. Dalam interaksi tersebut orang tua berusaha mempengaruhi anak untuk terlibat secara pikiran dan

\footnotetext{
${ }^{14}$ Roudhonah, Ilmu Komunikasi, (Cet. Ke-1; Jakarta: Kerja Sama Lembaga Penelitian UIN Jakarta dan Jakarta Pers, 2007), 93.

${ }^{15}$ Hafied Cangara, Pengantar Ilmu Komunikasi, (Cet. Ke-4; Jakarta: PT. Grafindo Persada, 2003), 99.
} 
emosi agar memperhatikan apa yang akan disampaikan. Sehingga terjadi proses belajar dalam diri anak terserbut.

b. Komunikasi Non Verbal

Komunikasi non verbal adalah komunikasi yang menggunakan bahasa isyarat atau bahasa diam (silent). ${ }^{16}$ Komunikasi non verbal dapat juga diartikan yaitu komunikasi dengan menggunakan gejala yang menyangkut dengan gerak-gerik (gestures), sikap (postures), ekspresi wajah (facial expressions), pakaian yang bersifat simbolik, isyarat dan gejala yang sama yang tidak menggunakan bahasa lisan dan tulisan. ${ }^{17}$

Berdasarkan beberapa pengertian di atas, dapat disimpulkan bahwa arti komunikasi non verbal adalah komunikasi yang proses pemyampaiannya tanpa katakata melainkan menggunakan isyarat, seperti sikap tubuh, gerak tubuh, ekspresi mata, ekspresi wajah, kedekatan jarak dan sentuhan.

Allah secara tegas memerintahkan di dalam Al-Qur'an bahwa cara berkomunikasi yang dapat digunakan orang tua untuk menyampaikan pesan kepada anak adalah dengan lemah lembut. Hal tersebut tercermin dari firman Allah swt:

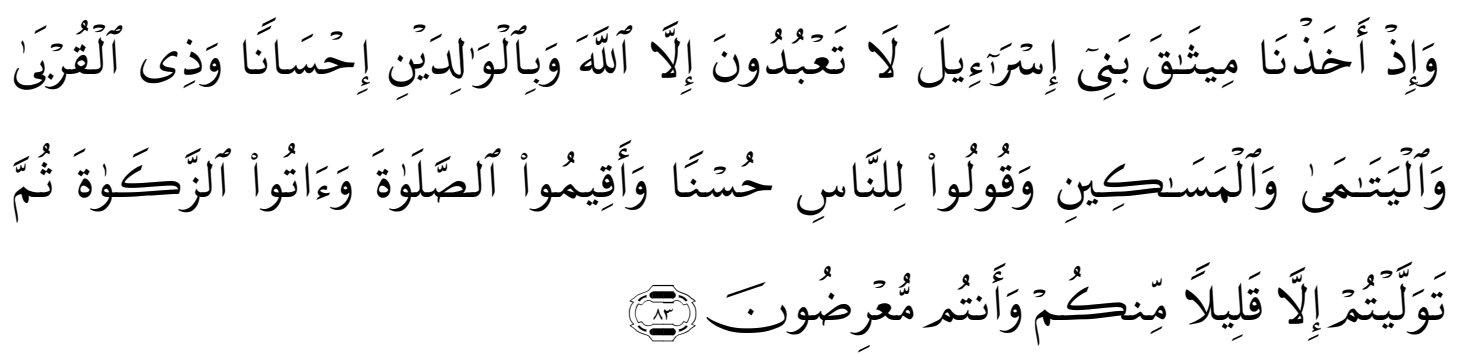

Terjemahnya:

"Dan (ingatlah), ketika Kami mengambil janji dari Bani Israil (yaitu): janganlah kamu menyembah selain Allah, dan berbuat kebaikanlah kepada ibu bapak, kaum kerabat, anak-anak yatim, dan orang-orang miskin, serta ucapkanlah kata-kata yang baik kepada manusia, dirikanlah shalat dan tunaikanlah zakat. kemudian

\footnotetext{
${ }^{16}$ Muhammad, Arni, Komunikasi Organisasi, (Cet. ke- 4., Jakarta: Bumi Aksara, 2001), 94-95.

${ }^{17}$ Onong Uchjana Effendi, Dimensi-dimensi Komunikasi, (Cet. Ke-4., Bandung: PT. Remaja Rosdakarya, 2004), 28.
} 
kamu tidak memenuhi janji itu, kecuali sebahagian kecil daripada kamu, dan kamu selalu berpaling. (Q.S Al-baqarah: 83$)^{18}$

Kalimat mengandung anjuran untuk berucap yang baik dan bersikap yang lembut kepada manusia termasuk dalam hal itu adalah pelaksanann amal ma'ruf nahi munkar (menyuruh berbuat baik dan mencegah kemunkaran). Jadi, setelah Allah SWT memerintahkan bani israil untuk berbuat baik kepada manusia dengan tindakan nyata, Allahpun menyuruh mengucapkan yang baik kepada manusia. ${ }^{19}$

Berdasarkan hal tesebut dapat disimpulkan bahwa jika orang tua akan menyampaikan pesan kepada anak hendaknya dilakukan dengan menggunakan cara yang baik, bahasa yang baik dan sikap yang lemah lembut. Sebab dengan cara seperti itu pesan ataupun nasihat yang disampaikan dapat diterima dan menjadi bahan evaluasi diri bagi anak tersebut.

Selain itu juga, komunikasi dapat dapat digunakan sebagai sarana untuk saling menasehati antar individu agar perilaku orang lain yang dianggap menyimpang dapat diperbaiki. Menasehati dan menetapi suatu perilaku yang baik itu sangatlah sulit butuh kesabaran dalam menjalankanya. Sebagaimana firman Allah swt:

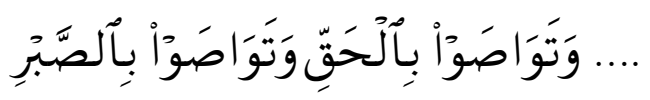

Terjemahnya:

"Dan nasehat menasehati supaya mentaati kebenaran dan nasehat menasehati supaya menetapi kesabaran. ${ }^{20}$

Kata tawashau terambil dari kata washa, washiyatan yang secara umum diartikan sebagai menyuruh secara baik. Sedangkan kata al-haqq berarti sesuatu yang

\footnotetext{
${ }^{18}$ Departemen Agama Republik Indonesia, Al-Qur'an dan Terjemahnya, (Surabaya: Duta Ilmu, 2002), 15.

${ }^{19}$ Abdul Ghoffar, Terjemahan Tafsir Ibnu Katsir jilid 1, (Jakarta: Pustaka Imam As-syafi'I, 2003), 174-175.

${ }^{20}$ Departemen Agama Republik Indonesia, Al-Qur'an, 913.
} 
mantap tidak berubah. ${ }^{21}$ Berdasarkan ayat tersebut diatas, salah satu cara agar tidak termasuk orang merugi yakni dengan saling menasehati dalam kebenaran. Manusia sejatinya merupakan agen of change yakni menjadi penggerak, memotivasi dan mendorong orang lain agar dapat berubah menjadi lebih baik. Dalam menasehati orang lain tentunya dengan cara yang baik dan dibutuhkan cara berkomunikasi yang baik pula, agar pesan yang disampaikan kepada orang lain dapat diterima dan menjadi bahan evaluasi diri bagi orang tersebut.

Menasehati dalam kebenaran merupakan kewajiban bagi seluruh manusia, tak terkecuali orang tua yang harus senantiasa memberikan nasehat kepada anak jika sekiranya terdapat hal-hal yang tidak baik telah dilakukan. Agar anak tersebut tumbuh dan berkembang menjadi pribadi yang baik.

\section{Minat Belajar Anak di Masa Pandemi Covid 19}

Minat secara etimologi berarti perhatian, kesukaan (kecenderungan) hati kepada suatu kegiatan. ${ }^{22}$ Sedangkan secara terminologi minat adalah perhatian yang mengandung unsur-unsur perasaan. Minat juga menetukan suatu sikap yang meyebabkan seseorang berbuat aktif dalam suatu pekerjaan. Dengan kata lain minat dapat menjadi sebab dari suatu kegiatan. ${ }^{23}$

Menurut Slameto minat adalah suatu rasa lebih suka dan rasa ketertarikan pada suatu hal atau aktivitas, tanpa ada yang menyuruh. Minat pada dasarnya adalah penerimaan akan suatu hubungan antara diri sendiri dengan sesuatu di luar diri. Semakin kuat atau dekat hubungan tersebut, semakin besar minat. ${ }^{24}$ Sardiman juga menyatakan bahwa minat adalah sebagai suatu kondisi yang terjadi, apabila melihat

\footnotetext{
${ }^{21}$ M. Quraish Sihab, Tafsir Al-misbah, (Jakarta: Lentera Hati, 2002), 496.

${ }^{22}$ WJS. Poerwodarminto, Kamus Umum Bahasa Indonesia (Jakarta: Balai Pustaka, 1984),

${ }^{23}$ Mahfud S., Pengantar Psikologi Pedidikan (Cet. IV; Surabaya: PT. Bina Ilmu, 2001), 92.

${ }^{24}$ Slameto, Belajar dan Faktor-faktor yang Mempengaruhinya, (Jakarta: Rineka Cipta, 2003),
} 1134. 180. 
ciri-ciri atau arti sementara situasi yang dihubungkan dengan kegiatan-kegiatan atau kebutuhan-kebutuhan sendiri. ${ }^{25}$

Minat merupakan sesuatu rasa yang timbul dari dalam diri seseorang atau peserta didik untuk condong kepada sesuatu yang ia sukai. Minat merupakan hal yang penting dimiliki oleh setiap anak, karena hal ini menyangkut rasa ketertarikannya terhadap sesuatu bidang atau mata pelajaran yang diajarkan oleh seorang pendidik di Sekolah agar tercapai suatu hasil belajar yang memuaskan.

Sedangkan belajar adalah suatu proses usaha yang dilakukan seseorang untuk memperoleh suatu perubahan tingkah laku yang baru secara keseluruhan, sebagai hasil pengalamannya sendiri dalam interaksi dengan lingkungannya. ${ }^{26}$ Menurut Fathurrohman, belajar adalah suatu kegiatan yang menimbulkan suatu perubahan tingkah laku yang relatif tetap dan perubahan itu dilakukan lewat kegiatan, atau usaha yang disengaja. ${ }^{27}$

Menurut Hilgard terkait dengan belajar, bahwa:

Belajar adalah proses perubahan melalui kegiatan atau prosedur latihan di dalam laboratorium maupun dalam lingkungan alamiah. Belajar bukanlah sekedar mengumpulkan pengetahuan, tetapi belajar adalah proses mental yang terjadi dalam diri seseorang, sehingga menyebabkan munculnya perubahan perilaku. $^{28}$

Berdasarkan pengertian belajar di atas dapat dirangkaikan pengertian belajar sebagai perangkat kegiatan dalam rangka memperoleh pengetahuan, pemahaman, pengenalan, pengalaman, pengamatan, membaca, mendengarkan, mengikuti petunjuk, kecakapan dan kepandaian.

\footnotetext{
${ }^{25}$ Sardiman, Guru dan Anak Didik dalam Interaksi Edukatif (Jakarta: Rineka Cipta, 2000), 224.

${ }^{26}$ Slameto, Belajar dan Faktor-faktor yang Mempengaruhinya (Cet. VI; Jakarta: Rineka Cipta, 2013), 2. 2012), 174.

${ }^{27}$ Muhammad Fathurrohman dan Sulistyorini, Belajar dan Pembelajaran (Yogyakarta: Teras,

${ }^{28}$ Wina Sanjaya. Strategi pembelajaran Berorientasi Standar Proses Pendidikan (Jakarta: Prenada Media Group, 2010), 112.
} 
Jadi minat belajar adalah aspek psikologi seseorang yang menampakkan diri dalam beberapa gejala, seperti gairah, keinginan, perasaan suka untuk melakukan proses perubahan tingkah laku melalui berbagai kegiatan yang meliputi mencari pengetahuan dan pengalaman, dengan kata lain minat belajar adalah perhatian, rasa suka, ketertarikan seseorang (anak) terhadap belajar yang ditunjukkan melalui keantusiasan, partisipasi dan keaktifan dalam belajar.

Ada tiga macam minat yang dikenal pada diri anak dalam dunia psikologi pendidikan yaitu minat volunter, involunter, dan non-volunter. Minat volunter adalah minat yang tumbuh dengan sendirinya dalam diri anak, minat involunter adalah minat yang ditimbulkan oleh seseorang melalui berbagai upaya penciptaan situasi yang kondusif, dan minat non-involunter adalah minat yang timbul dengan dipaksakan. Dengan demikian minat yang kuat, anak akan melakukan suatu tindakan dengan motivasi yang lebih tinggi disertai kepuasaan tertentu. ${ }^{29}$

Pada umumnya minat seseorang terhadap sesuatu diekpresikan melalui kegiatan atau aktivitas yang berkaitan dengan minatnya, sehingga untuk mengetahui indikator minat dapat dilihat dengan cara menganalisa kegiatankegiatan yang dilakukan individu atau objek yang disenanginya, karena minat merupakan motif yang dipelajari yang mendorong individu untuk aktif dalam kegiatan tertentu.

Menghadapi perubahan pola aktivitas dalam dunia pendidikan di masa Pandemi covid 19, Pemerintah menerbitkan Surat Edaran Mendikbud Nomor 4 Tahun 2020 dimana salah satunya berisi mengenai belajar dari rumah (learn form home) bagi peserta didik dan bekerja dari rumah (work from home) bagi tenaga pendidik dan kependidikan. Hal tersebut mengakibatkan proses belajar mengajar dilakukan secara daring. Bagi pendidikan di Indonesia, kondisi ini termasuk fenomena yang tidak terduga bagi guru, peserta didik, maupun orang tua. Hal tersebut dikarenakan kurang siapnya pendidikan di Indonesia terutama guru dalam pengaplikasian teknologi saat

\footnotetext{
${ }^{29}$ Surya, Kapita Selekta Kependidikan SD, (Jakarta: UT, 2001), 731.
} 
proses pembelajaran. Akibat kurang optimalnya pembelajaran daring tersebut mengakibatkan peserta didik merasa jenuh, bosan, dan stress sehingga peserta didik akan cenderung kurang minat terhadap pembelajaran yang berlangsung. ${ }^{30}$

Berdasarkan hasil analisis literatur jurnal diperoleh informasi bahwa bahwa ada sebagian peserta didik yang tidak mau mengikuti pembelajaran daring dan tidak mau mengerjakan tugas pembelajaran daring yang diberikan oleh guru jika orang tua tidak mendampingi dan membimbing peserta didik. Hasil wawancara dengan orang tua menunjukkan bahwa orang tua sangat berperan penting dalam menumbuhkan minat peserta didik dengan cara yaitu orang tua harus selalu mendampingi dan membimbing peserta didik pada saat proses pembelajaran daring berlangsung, agar peserta didik mempunyai minat yang tinggi dalam mengikuti pembelajaran daring. ${ }^{31}$

Proses pembelajaran dimasa pandemi covid 19 menuntut seorang guru untuk lebih mengerahkan perhatiannya dalam mengamati segala kegiatan-kegiatan peserta didiknya, apalagi dengan keterbatasan dalam bertatap muka secara langsung. Olehnya itu, kerjasama antar pihak sangat diperlukan, terlebih dengan orang tua peserta didik tersebut agar minat dalam belajar masih dapat terjaga.

Pada umumnya hal-hal yang dapat melemahkan minat peserta didik yakni proses pembelajaran yang hanya lebih cenderung pada bentuk penugasan. Peserta didik diberikan tugas-tugas untuk diselesaikan kemudian dikoreksi oleh guru sebagai bentuk penilaian dan diberikan komentar sebagai bentuk evaluasi tanpa ada penjelasan lebih lanjut mengenai materi yang diberikan. Hal inilah yang membuat anak mengalami bosan dan stress, sehingga minat belajarnya cepat berubah dan dari situlah dapat memengaruhi prestasi belajarnya.

\footnotetext{
${ }^{30}$ Subarto. Momentum of Families Developing the Learning Ability of Students Amid the Covid-19 Pandemic. (Adalah: Law and Justice Bulletin, 4, 13-18, 2020).

${ }^{31}$ Ria Fajrin Rizqy Ana, Peran Orang tua dalam Menumbuhkan minat belajar siswa pada Pembelajaran daring di SDN Kamulan 01 Kecamatan Talun Kabupaten Blitar. (Jurnal bidang Pendidikan Dasar, Volume 5 Nomor 2, Juni 2021), 177-186.
} 
Ada beberapa indikator seorang anak memiliki minat belajar yang tinggi. Hal ini dapat dikenali melalui proses belajarnya, di antaranya:

a. Perasaan senang.

Seorang anak yang memiliki perasaan senang atau suka terhadap pelajaran, maka ia harus terus mempelajari ilmu yang berhubungan dengan mata pelajaran tersebut. Sama sekali tidak ada perasaan terpaksa untuk mempelajari bidang tersebut. b. Perhatian dalam belajar.

Adanya perhatian juga menjadi salah satu indikator minat. Perhatian merupakan konsentrasi atau aktifitas jiwa kita terhadap pengamatan, pengertian, dan sebagainya dengan mengesampingkan yang lain dari pada itu. Seorang anak yang memiliki minat pada objek tertentu maka dengan sendirinya dia akan memperhatikan objek maka ia berusaha untuk memperhatikan penjelasan dari gurunya

c. Bahan pelajaran dan sikap guru yang menarik.

Tidak semua anak menyukai suatu bidang studi pelajaran karena faktor minatnya sendiri. Ada yang mengembangkan minatnya terhadap bidang pelajaran tersebut karena pengaruh dari gurunya, teman sekelas, bahan pelajaran yang menarik. Walaupun demikian lama-kelamaan jika anak mampu mengembangkan minatnya yang kuat terhadap mata pelajaran niscaya ia bisa memperoleh prestasi yang berhasil sekalipun ia tergolong anak yang berkemampuan rata-rata.

Sebagaimana dikemukakan oleh Brown bahwa tertarik kepada guru, artinya tidak membenci atau bersikap acuh tak acuh, tertarik kepada mata pelajaran yang diajarkan, mempunyai antusias yang tinggi serta mengendalikan perhatiannya terutama kepada guru, ingin selalu bergabung dalam kelompok kelas, ingin identitas dirinya diketahui oleh orang lain, tindakan kebiasaan dan moralnya selalu dalam control diri, selalu mengingat pelajaran dan mempelajarinya kembali, dan selalu terkontrol oleh lingkungannya ${ }^{32}$

${ }^{32}$ Ali Imran, Belajar dan Pembelajaran, (Cet. ke-3; Jakarta: PT Dunia Pustaka Jaya, 2006), 88 . 
d. Manfaat dan Fungsi Mata Pelajaran

Selain adanya perasaan senang, perhatian dalam belajar dan juga bahan pelajaran serta sikap guru yang menarik. Adanya manfaat dan fungsi pelajaran juga merupakan salah satu indikator minat. Karena setiap pelajaran mempunyai manfaat dan fungsinya.

Berdasarkan hal tersebut sangat jelas bahwa, untuk melihat minat anak dalam mengikuti pembelajaran di masa pandemi yakni berdasarkan indikator adanya perasaan senang anak dalam mengikuti proses pembelajaran, fokus dengan tugas yang diberikan oleh guru tanpa menunda-nunda dalam pengumpulannya, mempunyai antusias yang tinggi serta sadar dengan manfaat dan fungsi pelajaran yang diikuti misalnya ketika mengikuti pembelajaran dengan baik maka akan memperkuat ingatan anak terhadap apa yang telah dipelajarinya. Sehingga bisa dijadikan sebagai fondasi anak dalam proses pembelajaran berikutnya.

Menurut Slameto minat seseorang dalam belajar dapat dilihat dari indikatorindikator yaitu: ${ }^{33}$

a. Adanya rasa ketertarikan terhadap pelajaran dimana seseorang peserta didik dapat dikatakan memiliki minat belajar yang tinggi jika ia merasa tertarik pada suatu objek. Ketertarikan peserta didik tersebut akan berimplikasi pada indikator-indikator minat belajar yang lainnya. Maka kunci pertama dalam belajar adalah peserta didik terlebih dahulu mesti mempunyai rasa ketertarikan pada pelajaran.

b. Adanya pemusatan perhatian. Ketertarikan siswa dalam belajar akan memunculkan rasa perhatian yang terpusat (fokus). Ia akan memperhatikan setiap gerak-gerik guru dalam menyajikan pelajaran. Jika ada penugasan, baik dalam bentuk individu maupun kelompok, peserta didik akan tetap terfokus perhatiannya untuk menyelesaikan tugas-tugas tersebut.

\footnotetext{
${ }^{33}$ Slameto, Belajar dan Faktor-faktor yang Mempengaruhinya, (Jakarta: Rineka Cipta, 2003), 57.
} 
c. Adanya keingintahuan yang besar yaitu rasa ingin tahu yang besar akan muncul jika peserta didik sudah tertarik dan terpusat perhatiannya. Mereka akan mendalami suatu pelajaran secara mendetail peserta didik yang demikian pada tataran berikutnya akan dengan mudah menguasai dan memahami pelajaran.

d. Adanya kebutuhan terhadap pelajaran yaitu ketertarikan, perhatian yang terpusat, butuh akan ilmu pengetahuan. Kebutuhan yang dirasakan peserta didik ini akan berkorelasi positif dengan aktivitas belajar mereka ketika mengikuti pelajaran.

e. Adanya perasaan senang dalam belajar. Peserta didik yang senang terhadap suatu pelajaran akan mempelajarinya dengan sungguh-sungguh karena adanya daya tarik baginya, perasaan senang dalam belajar itulah yang menjadi acuan adanya kecenderungan minat dalam diri anak.

Berdasarkan keempat indikator di atas, maka sudah dapat dipastikan bahwa anak akan merasa senang dalam mengkaji suatu pelajaran. Kesenangan yang timbul ini terkait erat dengan keempat indikator tadi. anak bersuka ria dan bergembira, serta bahagia jika mengikuti pelajaran meski hanya dilakukan di Rumah.

\section{Pentingnya Komunikasi Orang Tua dalam Meningkatkan Minat Belajar Anak}

Orang tua merupakan pendidikan utama dan pertama bagi anak. Pada umumnya pendidikan dalam keluarga tidak lahir secara terstruktur dan kesadaran mendidik melainkan karena secara koadrat memberi secara alami membangun situasi pendidikan. Ibu adalah orang dan teman pertama yang didapatkan anak. Oleh sebab itu anak akan meniru apa yang dilakukan oleh ibu. Dalam Islam pendidikan pertama yang dilakukan oleh orang Islam adalah pendidikan keluarga. Situasi pendidikan itu terwujud berkat adanya pergaulan dan hubungan pengaruh mempengaruhi secara timbal balik antara orang tua dan anak. ${ }^{34}$

${ }^{34}$ Zakiah Daradjat, Ilmu Pendidikan Islam, (Cet. X; Jakarta: Bumi Aksara, 2012), 35. 
Pendidikan orang tua terhadap anak-anaknya adalah pendidikan yang didasarkan pada rasa kasih sayang terhadap anak-anak dan yang diterimanya dari kodrat. Orang tua adalah pendidik sejati, pendidik karena kodratnya. Oleh karena itu, kasih sayang orang tua terhadap anak-anak hendaklah kasih sayang yang sejati pula. ${ }^{35}$

Berdasarkan hal tersebut memberikan gambaran bahwa pendidikan utama dalam keluarga telah menjadi ketentuan untuk dijalankan oleh orang tua sebagai pendidik sejati bagi anak dalam segala aspek. Hasan langgulung mengatakan bahwa pada hakikatnya orang tua memiliki fungsi untuk menanamkan sifat mencintai, menjaga kesehatan, kejiwaan spiritual, akhlak, jasmani, emosional, sosial dan lain sebagainya. ${ }^{36}$

Sebagaimana firman Allah dalam Al-Qur'an surat At-tahrim ayat 6:

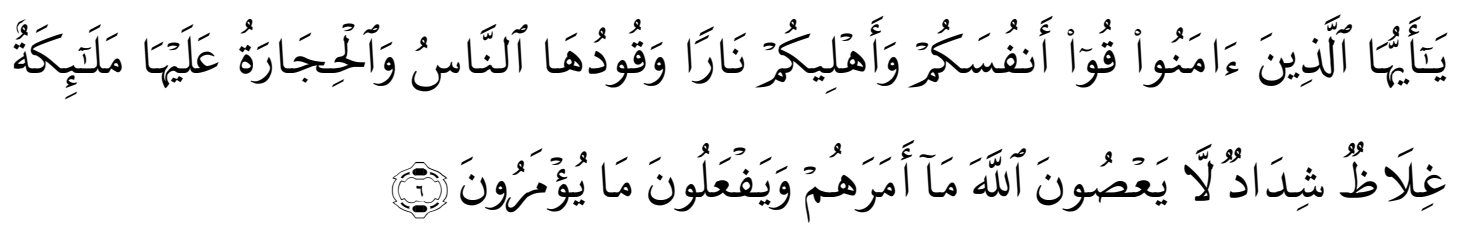

Terjemahnya :

Hai orang-orang yang beriman, peliharalah dirimu dan keluargamu dari api neraka yang bahan bakarnya adalah manusia dan batu, penjaganya malaikatmalaikat yang kasar, keras dan tidak mendurhakai Allah terhadap apa yang diperintahkan-Nya kepada mereka dan selalu mengerjakan apa yang diperintahkan. ${ }^{37}$

Pemegang peranan terpenting bagi anak pada kebanyakan keluarga adalah ibu. Sejak anak dilahirkan ibulah yang selalu di sampingnya, memberikan berbagai bentuk kasih sayang, memelihara, menjaga, serta berkomunikasi secara personal dengan anak.

\footnotetext{
${ }^{35}$ M. Ngalim Purwanto, Ilmu Pendidikan Teoritis dan Praktis, (Bandung: PT. Remaja Rosdakarya,2009), 80.

${ }^{36}$ Ramayulis, dkk, Filsafat Pendidikan Islam, (Cet. 1, Jakarta: Kalam Mulia, 2009), 147.

${ }^{37}$ Departemen Agama Republik Indonesia, Al-Qur'an dan Terjemahnya, (Surabaya: Duta Ilmu, 2002), 820.
} 
Pendidikan seorang ibu terhadap anaknya merupakan pendidikan dasar yang harus diperhatikan dan tidak dapat diabaikan sama sekali. Oleh karena itu, ibu hendaklah memiliki sifat bijaksana dan pandai dalam mendidik anak-anaknya. sebab terdapat pernyataan bahwa seorang ibu merupakan pendidik bangsa. Hal ini menjadi dasar betapa beratnya peran orang tua dalam membina dan mendidik anak-anaknya.

Setiap orang tua tentunya sangat mengusahakan anak-anaknya menjadi generasi yang tangguh dan berkualitas, hal ini diperlukan adanya usaha yang konsisten dan kontinu dari orang tua di dalam melaksanakan perannya, baik memelihara, mengasuh dan mendidik anak-anak mereka secara lahir maupun batin, sampai anak tersebut dewasa atau mampu berdiri sendiri, dimana tugas ini merupakan kewajiban orang tua. Begitu pula halnya terhadap pasangan suami istri yang berakhir perceraian, ayah dan ibu tetap berkewajiban untuk memelihara, mengasuh dan mendidik anak-anaknya. ${ }^{38}$

Secara sederhana, peran orang tua dapat dijelaskan pula sebagai suatu kewajiban orang tua kepada anak. Diantaranya adalah orang tua wajib memenuhi hak-hak (kebutuhan) anaknya. seperti hak untuk melatih anak menguasai cara-cara mengurus diri sendiri misalnya berjalan, berbicara, cara makan, berdo'a yang erat kaitannya dengan perkembangan diri anak sebagai pribadi. Sikap orang tua sangat mempengaruhi perkembangan anak. Sikap menerima atau menolak, sikap kasih sayang atau acuh tak acuh, sikap sabar atau tergesa-gesa, sikap melindungi atau membiarkan yang secara langsung mempengaruhi reaksi emosional anak. ${ }^{39}$

Peran orang tua juga masuk keranah pendidikan anak tersebut di Sekolah. Anak ketika telah memasuki pendidikan formal bukan secara mutlak tugas guru di sekolah dalam melatih, membina dan mendidik anak tersebut, namun harus bersinergi antara semua pihak termasuk orang tua anak tersebut di Rumah. Selama proses pembelajaran di masa pandemi covid 19, pembelajaran secara daring dilakukan tidak

${ }^{38}$ Mahmud Gunawan dkk, Pendidikan Agama Islam dalam Keluarga, (Jakarta: Akademia Permata, 2013), 132.

${ }^{39}$ Hasbullah, Dasar-dasar Ilmu Pendidikan, (Jakarta: RajaGrafindo Persada, 2011), 88. 
hanya di Indonesia melainkan diseluruh penjuru dunia. Dalam segi pendidikan pembelajaran daring tentunya tidak terlepas dari peran orang tua. Orang tua diharapkan mendampingi anak ketika pembelajaran sedang berlangsung yang diberlakukan melalui berbagai aplikasi yang digunakan seperti Zoom meeting, google meet, Classroom, Whatsapp dan lain sebagainya.

Banyak kasus yang terjadi akibat kebijakan yang diberlakukan saat ini dan lebih cenderung muncul yakni menurunnya minat belajar anak. Ada beberapa faktor yang mempengaruhi minat belajar anak yaitu:

a. Motivasi

Minat seseorang akan semakin tinggi bila disertai motivasi, baik yang bersifat internal ataupun eksternal. Menurut D.P. Tampubolon minat merupakan perpaduan antara keinginan dan kemampuan yang dapat berkembang jika ada motivasi. ${ }^{40}$

b. Belajar

Minat dapat diperoleh melalui belajar, karena dengan belajar anak yang semula tidak menyenangi suatu pelajaran tertentu, lama kelamaan lantaran bertambahnya pengetahuan mengenai pelajaran tersebut, minat pun tumbuh sehingga peserta didik akan lebih giat lagi mempelajari pelajaran tersebut. Hal ini sesuai dengan pendapat Singgih D. Gunarsa bahwa minat akan timbul dari sesuatu yang diketahui dan kita dapat mengetahui sesuatu dengan belajar, karena itu semakin banyak belajar semakin luas pula bidang minat. ${ }^{41}$

c. Bahan Pelajaran dan Sikap Guru

Faktor yang dapat membangkitkan dan merangsang minat adalah faktor bahan pelajaran yang akan diajarkan kepada anak. Bahan pelajaran yang menarik minat anak, akan sering dipelajari oleh anak yang bersangkutan. Sebaliknya, bahan pelajaran yang tidak menarik tentu akan dikesampingkan oleh anak tersebut.

\footnotetext{
${ }^{40}$ D.P. Tampubolon, Mengembangkan Minat Membaca pada Anak (Cet. VI; Bandung: Angkasa, 2003), 41.

${ }^{41}$ Singgih D.Gunarsa, Psikologi Perawatan (Cet. IX; Jakarta: BPK Gunung Mulia, 2004), 68.
} 
Guru juga salah satu obyek yang dapat merangsang dan membangkitkan minat belajar anak. Menurut Kurt Singer bahwa guru yang berhasil membina kesediaan belajar anak didiknya, berarti telah melakukan hal-hal yang terpenting yang dapat dilakukan demi kepentingan anak tersebut. ${ }^{42}$

d. Keluarga

Keluarga sangat berpengaruh dalam menentukan minat seorang anak terhadap pelajaran. Apa yang diberikan oleh keluarga sangat berpengaruhnya bagi perkembangan jiwa anak. Dalam proses perkembangan minat diperlukan dukungan perhatian dan bimbingan dari keluarga khususnya orang tua.

e. Lingkungan

Melalui lingkungan pergaulan akan mempengaruhi minat peserta didik. Hal ini ditegaskan oleh pendapat yang dikemukakan oleh Crow\& Crow bahwa minat dapat diperoleh dari kemudian sebagai dari pengalaman mereka dari lingkungan di mana mereka tinggal. Lingkungan sangat berperan dalam pertumbuhan perkembangan anak. Lingkungan adalah keluarga yang mengasuh dan membesarkan anak, sekolah tempat mendidik, masyarakat tempat bergaul, juga tempat bermain sehari-hari dengan keadaan alam dan iklimnya, flora serta faunanya. Besar kecilnya terhadap pertumbuhan dan perkembangan bergantung kepada keadaan lingkungan peserta didik itu sendiri serta jasmani dan rohaninya. ${ }^{43}$

Hasil uraian di atas, diketahui bahwa keluarga merupakan salah satu faktor penting dalam menumbuhkan minat belajar anak. Pada analisis literatur jurnal atas nama Ria Fajrin Rizky Ana dengan judul peran orang tua dalam meningkatkan minat belajar siswa pada pembelajaran daring di SDN Kamulan 01 Kecamatan Talun Kabupaten Blitar di dapatkan informasi bahwa, peran orang tua dalam menumbuhkan minat belajar anak pada pembelajaran Daring menunjukkan bahwa peran orang tua sangat penting dalam menumbuhkan minat belajar anak. Peran orang tua dalam

\footnotetext{
${ }^{42}$ Kurt Singer, Membina Hasrat Belajar di Sekolah, (Terj. Bergman Sitorus), (Cet. IV; Bandung: Remaja Rosda Karya, 2003), 93.

${ }^{43}$ Ibid., 104.
} 
menumbuhkan minat belajar anak termasuk dalam kategori sangat tinggi, dengan mengacu pada 4 indikator yaitu peran orang tua sebagai pendidik (educator), peran orang tua sebagai pendorong (motivator), peran orang tua sebagai fasilitator, dan peran orang tua sebagai pembimbing. Minat belajar anak pada pembelajaran daring juga termasuk dalam kategori tinggi. ${ }^{44}$

Hal ini sesuai dengan hasil jurnal atas nama Sintia Septiani dkk dengan judul peran orang tua dalam meningkatkan minat belajar anak pada masa pandemi covid 19 bahwa dengan adanya pembelajaran di rumah mengembalikan tanggung jawab hakikat pendidikan pertama dan utama yaitu pendidikan di dalam keluarga. Oleh karena itu, peranan orang tua dalam pembelajran online ini sangat penting dalam memberikan minat belajar anak. Peran orang tua selama pembelajaran online atau di rumah diantaranya sebagai pembimbing, fasilitator, dan motivator. Tetapi tetap saja selama pembelajaran online ini tidak terlepas dari komunikasi yang terjadi antara guru dan orang tua. Tetapi disisi lain pembelajaran online tetap saja membuat anak mengalami bosan dan stress, sehingga minat belajar anak cepat berubah dan dari situlah dapat mempengaruhi prestasi belajarnya. Oleh karena itu, orang tua sebagai orang yang terdekat dengan anak memiliki peran yang sangat penting dalam meningkatkan minat dan prestasi belajar anak diantaranya dengan memberikan semangat, motivasi, memfasilitasi kebutuhan belajar anak, menjadi tempat untuk bertanya tentang pelajaran dan memberikan apresiasi pada anak untuk setiap pencapaian anak yang telah diraih. ${ }^{45}$

Berdasarkan hal tersebut di atas, menunjukkan bahwa betapa pentingnya peranan orang tua, terutama dalam meningkatkan minat belajar anak. Sebab hal yang sering terjadi adalah menurunnya minat belajar anak dengan munculnya kejenuhan dalam belajar, malas mengerjakan tugas, bahkan lebih memilih bermain game

\footnotetext{
${ }^{44}$ Ria Fajrin Rizky Ana, Peran Orang tua dalam Meningkatkan Minat Belajar Siswa pada Pembelajaran Daring di SDN Kamulan 01 Kecamatan Talun Kabupaten Blitar, (Jurnal Bidang Pendidikan Dasar, Volume 5 Nomor 2 Tahun 2021), 177-186.

${ }^{45}$ Sintia Septiani dkk, Peran orang tua dalam meningkatkan minat belajar Anak Pada masa pandemic covid 19, (Jurnal Edumaspul, Volume 5 Nomor 2 Tahun 2021), 49-55.
} 
dibandingkan belajarnya. Hal ini diakibatkan tidak adanya pantauan secara langsung dari seorang guru, tidak adanya teman belajar dan lain sebagainya. Oleh karena itu, orang tua bertanggung jawab dalam menjalankan tugasnya di Rumah dengan senantiasa menerapkan komunikasi baik secara verbal maupun non verbal dalam bentuk pemberian semangat dan dorongan kepada anak, memberikan nasihat atau edukasi agar anak dapat meningkatkan minat belajarnya untuk mencapai hasil yang lebih baik dan maksimal. Karena pembelajaran online dinilai tetap mampu meningkatkan kualitas pembelajaran jika orang tua ikut serta membantu mendampingi anak dalam belajarnya.

\section{PENUTUP}

Berdasarkan keseluruhan uraian mengenai Peran Komunikasi Orang tua dalam Meningkatkan Minat Belajar Anak di Masa Pandemi Covid 19, maka penulis mengemukakan beberapa kesimpulan bahwa:

1. Komunikasi antara orang tua terhadap anak dilakukan dalam dua bentuk yakni secara verbal dan non verbal dengan menggunakan cara yang baik, bahasa yang baik dan sikap yang lemah lembut. Hal ini dilakukan dengan tujuan bahwa pesan ataupun nasihat yang disampaikan dapat diterima dan menjadi bahan evaluasi diri bagi anak.

2. Pada umumnya tingkatan Minat belajar anak di masa Pandemi Covid 19 menunjukkan hasil yang belum baik, hal ini dapat timbul akibat kurang optimalnya pembelajaran daring tersebut sehingga mengakibatkan anak merasa jenuh, bosan dan stress sehingga anak sering terlambat dalam mengerjakan tugas yang diberikan bahkan tidak dikerjakan, anak lebih senang bermain game dibandingkan belajar, anak memilih untuk bermain ataupun tidur saat proses pembelajaran berlangsung, tidak memiliki catatan belajar dan lain sebagainya.

3. Peran komunikasi orang tua dalam meningkatkan minat belajar anak sangatlah penting, sebab orang tua merupakan pendidik utama bagi anak di Rumah. orang tua bertanggung jawab dalam menjalankan tugasnya dengan senantiasa 
memberikan semangat dan dorongan kepada anak, memberikan nasihat atau edukasi agar anak dapat meningkatkan minat belajarnya untuk mencapai hasil yang lebih baik dan maksimal. Karena pembelajaran online dinilai tetap mampu meningkatkan kualitas pembelajaran jika orang tua ikut serta membantu mendampingi anak dalam belajarnya.

\section{DAFTAR PUSTAKA}

Abdul Ghoffar, Terjemahan Tafsir Ibnu Katsir jilid 1, Jakarta: Pustaka Imam AsSyafi' I, 2003.

Ana, Ria Fajrin Rizky. Peran Orang tua dalam Meningkatkan Minat Belajar Siswa pada Pembelajaran Daring di SDN Kamulan 01 Kecamatan Talun Kabupaten Blitar, Jurnal Bidang Pendidikan Dasar, Volume 5 Nomor 2 Tahun 2021.

Azzet, Akhmad Muhamimin. Urgensi Pendidikan Karakter di Indonesia, Jogjakarta: Ar-Ruzz Media, 2011.

Cangara, Hafied. Pengantar Ilmu Komunikasi, Jakarta: PT. Raja Grafindo Persada, 2006.

Daradjat, Zakiah. Ilmu Pendidikan Islam, Cet. X, Jakarta: Bumi Aksara, 2012.

Departemen Agama Republik Indonesia, Al-Qur'an dan Terjemahnya, Surabaya: Duta Ilmu, 2002.

Departemen Agama RI, Al-Qur'an dan Tafsirnya, Jakarta: Lentera Abadi, 2010.

Effendi, Onong Uchjana. Dimensi-dimensi Komunikasi, (Cet. Ke-4., Bandung: PT. Remaja Rosdakarya, 2004.

Effendi, Onong Uchjana. Ilmu Komunikasi Teori dan Praktek, Cet. 20; Bandung: Rosdakarya, 2007.

Effendy, Onong Uchjana. Dinamika Komunikasi, Bandung: PT. Remaja Rosda Karya, 2000 .

Fajar, Marheini. Ilmu Komunikasi, Teori dan Praktek, Edisi 1, Yogyakarta: Graha Ilmu, 2009. 
266 | MUSA WA, Vol. 13 No.2 Desember 2021 : 243-267

Fathurrohman, Muhammad. Sulistyorini, Belajar dan Pembelajaran, Yogyakarta: Teras, 2012.

Gunarsa, Singgih D. Psikologi Perawatan, Cet. IX; Jakarta: BPK Gunung Mulia, 2004.

Gunawan, Mahmud. dkk, Pendidikan Agama Islam dalam Keluarga, Jakarta: AkademiaPermata, 2013.

Hafied Cangara, Pengantar Ilmu Komunikasi, (Cet. Ke-4., Jakarta: PT. Grafindo Persada, 2003.

Hasbullah, Dasar-dasar Ilmu Pendidikan, Jakarta: RajaGrafindo Persada, 2011.

Imran, Ali. Belajar dan Pembelajaran, Cet, ke-3; Jakarta: PT Dunia Pustaka Jaya, 2006.

Muhammad, Arni, Komunikasi Organisasi, Cet. ke- 4; Jakarta: Bumi Aksara, 2001.

Munir, Abdullah. Membangun Komunikasi Efektif: Sebuah Upaya Mewujudkan Sekolah yang Membahagiakan. Yogyakarta: Mentari Pustaka, 2012.

Poerwodarminto, WJS. Kamus Umum Bahasa Indonesia. Jakarta: Balai Pustaka, 1984.

Purwanto, M. Ngalim. Ilmu Pendidikan Teoritis dan Praktis, Bandung: PT. Remaja Rosdakarya, 2009.

Ramayulis, dkk, Filsafat Pendidikan Islam, Cet. 1, Jakarta: Kalam Mulia, 2009.

Ria Fajrin Rizqy Ana, Peran Orang tua dalam Menumbuhkan minat belajar siswa pada Pembelajaran daring di SDN Kamulan 01 Kecamatan Talun Kabupaten Blitar. (Jurnal bidang Pendidikan Dasar, Volume 5 Nomor 2, Juni 2021.

Roudhonah, Ilmu Komunikasi, Cet. Ke-1; Jakarta: Kerja Sama Lembaga Penelitian UIN Jakarta dan Jakarta Pers, 2007.

S., Mahfud. Pengantar Psikologi Pedidikan, Cet. 4, Surabaya: PT. Bina Ilmu, 2001.

Saefullah, U. Manejemen Pendidikan Islam, cet. 1, Bandung: Pustaka Setia, 2012.

Salisah, Nikmah Hadiati. Ilmu Komunikasi, Pasuruan: LunarMedia, 2012. 
Durotunnisa, Peran Komunikasi ... | 267

Sanjaya, Wina. Strategi pembelajaran Berorientasi Standar Proses Pendidikan, Jakarta: Prenada Media Group, 2010.

Sardiman, Guru dan Anak Didik dalam Interaksi Edukatif, Jakarta: Rineka Cipta, 2000.

Sardiman, Interaksi dan Aktivitas Belajar Mengajar, Jakarta: Rajawali Pers, 2004.

Septiani, Sintia. dkk, Peran orang tua dalam meningkatkan minat belajar Anak Pada masa pandemic covid 19, Jurnal Edumaspul, Volume 5 Nomor 2 Tahun 2021.

Sihab, M. Quraish. Tafsir Al-Misbah, Jakarta: Lentera Hati, 2002.

Singer, Kurt. Membina Hasrat Belajar di Sekolah, Terj. Bergman Sitorus, Cet. IV; Bandung: Remaja Rosda Karya, 2003.

Slameto, Belajar dan Faktor-faktor yang Mempengaruhinya, Jakarta: Rineka Cipta, 2003.

Soyomukti, Nurani. Pengantar Ilmu Komunikasi, Jogjakarta: Ar- Ruzz Media, 2010.

Subarto. Momentum of Families Developing the Learning Ability of Students Amid the Covid-19 Pandemic. Adalah: Law and Justice Bulletin, 4, 13-18, 2020.

Surya, Kapita Selekta Kependidikan SD, (Jakarta: UT, 2001), 731

Tampubolon, D.P. Mengembangkan Minat Membaca pada Anak Cet. VI; Bandung: Angkasa, 2003.

Vardiansyah, Filsafat Ilmu Komunikasi, Jakarta: PT Indeks Gramedia, 2005. 